\title{
“NO MEIO CRESCE INSONDÁVEL \\ O VAZIO": \\ APROXIMAÇÕES ENTRE AS POÉTICAS DE JOSÉ CRAVEIRINHA E PAULA TAVARES
}

\author{
Patrícia Ribeiro \\ (Universidade Federal de Juiz de Fora)
}

\section{RESUMO}

Este trabalho propõe uma leitura comparada entre a poesia da escritora angolana Paula Tavares e a do autor moçambicano José Craveirinha a fim de analisar a presença do erotismo nos versos desses poetas. Essa investigação busca demonstrar que o erotismo manifesta-se na poética de ambos os autores mediante o jogo de sedução e o posterior encontro dos amantes, o qual, às vezes, torna-se fugaz quando interceptado por fatos, explicitados e analisados ao longo deste texto, que geram profundo desalento no eu poético.

PALAVRAS-CHAVE: Poesia; Erotismo; Leitura comparada.

\section{ABSTRACT}

This work proposes a comparative reading of the poetry of Angolan writer Paula Tavares and that of Mozambican writer José Craveirinha in order to analyse the presence of eroticism in the verses of these poets. This research aims to demonstrate that eroticism manifests itself in both authors's poetics through a seduction game and the subsequent meeting of the lovers, which sometimes becomes fugitive when intercepted by facts, specified and analysed throughout this text, which generate deep discouragement in the lyric speaker.

KEYWORDS: Poetry; Eroticism; Comparative reading. 
As poéticas de José Craveirinha, escritor moçambicano, e de Paula Tavares, autora angolana, expressam questões que dizem respeito ao período que antecedeu e/ou que é posterior à independência de suas nações, levando também em consideração as particularidades culturais dos respectivos países aos quais os poetas pertencem, sem deixarem, no entanto, de também tocar no que concerne a uma dimensão universal. Neste trabalho, norteados pela perspectiva do que se refere ao universal, destacamos a expressão do erotismo na poesia de José Craveirinha e de Paula Tavares.

Segundo Georges Bataille (1980), o erotismo torna-se flagrante todas as vezes que o ser humano apresenta comportamentos que vão de encontro aos juízos habituais. Deslocando-se na direção oposta a ideias e condutas consideradas normativas, o erotismo expõe o mais substancial das pessoas, ele "deixa transparecer o avesso duma fachada, cuja aparência nunca é desmentida: nesse avesso se revelam sentimentos, partes do corpo e modos de ser que vulgarmente temos vergonha" (BATAILLE, 1980, p. 97, grifo do autor).

O erotismo como propulsor de um movimento que desvela o reverso das pessoas permite sua ratificação como "um dos aspectos da vida interior do homem" (BATAILLE, 1980, p. 27), aspecto esse que o conduz a, como observa Bataille (1980, p. 27), "pôr o seu ser em questão", uma vez que com a manifestação do erotismo o ser humano precisa lidar com as aspirações projetadas sobre seu objeto de desejo, mas também com sua vida interior ${ }^{1}$.

A relação entre os seres humanos implica a existência de um abismo, uma descontinuidade. O limiar desse abismo, tal como um indicativo iminente de morte, contudo, pode nos fascinar, pois para nós que somos seres descontínuos a morte ganha contornos de continuidade do ser: "a reprodução leva à descontinuidade dos seres, mas faz também intervir a sua continuidade, isto é, a reprodução está intimamente associada à morte" (BATAILLE, 1980, p. 14). A continuidade dos seres e a morte despertam uma fascinação que domina o erotismo.

A fim de melhor delimitar a relação entre a continuidade dos seres e a morte, vejamos algumas considerações sobre a reprodução sexual que, segundo o teórico francês, guia-nos a uma passagem da descontinuidade à continuidade:

O espermatozóide e o óvulo são, no estado elementar, seres descontínuos, mas que se unem e, em consequência estabelece-se entre eles uma continuidade que leva à formação dum novo ser, a partir da morte, do desaparecimento dos seres separados. O novo ser é em si mesmo descontínuo, mas traz em si a passagem à continuidade, a fusão, mortal para cada um deles, de dois seres distintos (BATAILLE, 1980, p. 15, grifo do autor). 
Dessa passagem cíclica do contínuo para o descontínuo e do descontínuo para o contínuo resta a nós, seres descontínuos, a "nostalgia da continuidade perdida" e o eterno anseio pela continuidade que nos une ao ser. E é essa falta, ou seja, a busca constante pela continuidade que também proporciona a manifestação, nos seres humanos, de três formas de erotismo: o erotismo dos corpos (materializado), o erotismo dos corações (recíproca afeição dos amantes) e o erotismo sagrado (a procura pelo amor de Deus). Essas distintas expressões do erotismo têm em comum a tentativa de obter uma substituição do isolamento do ser (sua descontinuidade) por uma continuidade (BATAILLE, 1980, p. 16-17).

Diante das proposições de Bataille sobre o erotismo e suas diferentes vertentes, este trabalho propõe-se a analisar, através de uma perspectiva comparada, a expressão do erotismo dos corpos na poesia de Paula Tavares, escritora angolana, e na de José Craveirinha, autor moçambicano.

O erotismo dos corpos manifesta-se no jogo de sedução e na posterior materialidade do encontro dos amantes, momento no qual se desvelam sentimentos, partes do corpo e modos de ser que usualmente despertam pudor nas pessoas (BATAILLE, 1980, p. 97). A esse respeito e tentando nos aproximar da expressão do erotismo dos corpos na poética dos autores em tela, vejamos um fragmento de "Cantiga nossa":

\author{
No minuto \\ em que os nervos se rasgaram \\ calou-se a voz dos gritos \\ calou-se a voz das ondas do mar \\ e o mundo estremeceu e parou \\ E um gemido \\ veio como um búzio \\ docemente soprar-me \\ entre as nuvens do céu \\ o teu corpo na terra \\ e a espuma do mar. \\ [...] \\ (CRAVEIRINHA, 2010, p. 53)
}

Os versos iniciais mostram a brevidade de um minuto no qual se consumou o encontro dos amantes que, por sua vez, é exposto através da imagem dos nervos que se rasgaram e do gemido. E em paralelo à morte (a passagem da descontinuidade para a continuidade) nesse fugaz momento, observamos que o mundo ao redor dos amantes também se mostra em confluência com essa morte metafórica, pois, nesse momento do encontro, os gritos e as ondas do mar silenciaram e o mundo "estremeceu e parou".

Em seguida, reitera-se o encontro dos amantes com a natureza, uma vez que o gemido, assim como o som propagado pelo búzio mediante seu sopro, transporta o eu poético para um espaço difuso, no qual se con- 
fundem as dimensões do céu, o contato com o corpo da amada na terra e as águas do mar. Mas, posteriormente a esse estado de opacidade, o eu poético transita para o estado de consciência de que do "minuto perfeito" emerge a plena harmonia entre ele e sua amada, como indicam os versos: "E do minuto perfeito/ ah, Maria Teresa/ brotou na praia docemente/ a nossa cantiga/ mais viva/ mais forte/ e mais nova!" (CRAVEIRINHA, 2010, p. 53).

A harmonia do encontro dos amantes é indicada desde o título do poema ("Cantiga"), visto que se pressupõe que a melodia de uma cantiga possui sonoridade agradável. A perfeição do enlace dos amantes, semelhante a essa cantiga, além de melodia harmônica também possui as capacidades de vivificação e de renovação ("a nossa cantiga/ mais viva/ mais forte/ e mais nova!") e ainda se mostra em consonância com o fluxo da natureza, pois esta acompanha a suavidade do encontro dos amantes, como mostram os versos citados.

Além disso, nesses versos, a expressão do erotismo de maneira semelhante à harmonia melódica de uma cantiga aponta para a necessidade de encararmos o erotismo não como um objeto exterior a nós, mas como "o movimento do ser em nós próprios" (BATAILLE,1980, p. 34), um movimento em busca pela continuidade, pela perfeita conjugação de sons e de ritmos e pelo equilíbrio dos desejos do corpo (físico) e das aspirações do ser.

Em paralelo a esse poema de Craveirinha, também vemos o encontro dos amantes, apresentado mediante a aproximação deste a um elemento da natureza, nos versos de "A curva do rio":

Desces a curva do meu corpo, amado

com o sabor da curva de outros rios

contas as veias e deixas as mãos pousarem

como asas

como vento

sobre o sopro cansado

sobre o seio desperto

[...]

(TAVARES, 2001, p. 26)

Em comparação a "Cantiga nossa”, de Craveirinha, poema no qual a voz poética apresenta-se com modulação de uma voz masculina (pois a voz se dirige à amada, Maria Teresa), nesses versos de Paula Tavares o eu poético possui modulação de uma voz feminina, como revela o primeiro verso que evoca a figura do amado. Sobre essa perspectiva de uma voz poética feminina, vale ressaltar que esses versos mostram-se em conformidade com uma tendência que, segundo Fonseca (2002, p. 44), vem ganhando força na produção poética elaborada por mulheres, a saber: a existência de uma inclinação para "vasculhar a intimidade do corpo e as expressões de seus desejos". 
Os versos citados expõem a aproximação do corpo feminino ao rio, indicando a associação da mulher à natureza, um recurso recorrente na literatura e que foi utilizado em diferentes épocas ${ }^{2}$, sendo, muitas vezes, aplicado por um discurso de perspectiva patriarcal e masculina na tentativa de instaurar a dominação sobre o feminino ${ }^{3}$. Entretanto, nesses versos, essa aproximação da mulher à natureza denota a imagem de um corpo feminino que, tal qual a liberdade das águas do rio ao seguir seu curso, coloca-se ao alcance do amado por vontade própria, contrariando a perspectiva segundo a qual, como observa Padilha (2006, p. 313), "tradicionalmente foi o sujeito lírico masculino quem liberou sua pulsão amorosa nas asas da poesia".

Conforme exprimem os versos, as mãos do amado perscrutam o corpo feminino, contando suas veias e, com a delicadeza das asas dos pássaros e do vento, as mãos pousam "sobre o seio desperto". Seguindo as considerações de Bataille (1980), notamos que o erotismo manifesta-se nesses versos a partir da materialidade do encontro dos corpos dos amantes que, por meio do desnudamento, conduz os indivíduos à continuidade almejada pelos seres descontínuos: "a nudez opõe-se ao estado fechado, ou seja, ao estado de existência descontínua. É um estado de comunicação que revela a procura duma possível continuidade do ser, para lá do isolamento a que cada um de nós está votado" (BATAILLE, 1980, p. 18).

Em seguida, da delicadeza inicial o encontro dos amantes adquire os tons do erotismo alicerçado em uma "irrupção, duma violência no momento da explosão” (BATAILLE, 1980, p. 83), a qual se exprime a partir da imagem do amado que, com sua canoa, percorre o rio (o corpo feminino) e "rasga a rede", encontrando a pele da amada em estado semelhante ao de outrora:

\author{
Parte a canoa e rasga a rede \\ tens sede de outros rios \\ olhos de peixe que não conheço \\ e dedos que sentem em mim a pele arrepiada \\ d'outro tempo
}

(TAVARES, 2001, p. 26)

A violência que diz respeito ao erotismo, nesses versos, decorre de seu aspecto intrínseco de violação, dado que a passagem dos seres descontínuos para um ainda que fugaz instante de continuidade (o momento da morte) é tida como um ato violento porque arranca o ser de sua obstinação de ver durar o ser descontínuo que ele constitui (BATAILLE, 1980, p. 17-18). Além dessa violência que envolve o erotismo, também notamos que o amado transfigura-se no momento da transição da descontinuidade para a continuidade, uma vez que ele é apresentado com "olhos de peixe" que a figura feminina não reconhece. No entanto, no tênue momento da continuidade, os amantes identificam-se pelo toque, pela "pele arrepiada" como ela fora nos tempos idos. 
Apesar de esses versos mostrarem a imagem de um corpo feminino que permite o contato com o amado, os versos finais endossam a presença do erotismo, mas apontam uma ressalva para o enlace dos amantes: “[...] andas em círculos de fogo/ à volta do meu cercado/ Não entres, por favor não entres/sem os óleos do começo/e as laranjas" (TAVARES, 2001, p. 27). Esses versos apontam para o erotismo com a imagem do amado que ronda a figura feminina deixando rastros de seu desejo, os "círculos de fogo", ao redor do cercado dela. O cercado simboliza os elementos que cercearam as mulheres angolanas, entraves impostos pela colonização ou representados pela própria tradição ancestral (PADILHA, 2002, p. 15). Portanto, para alcançar o corpo feminino, o amado deve cumprir os ritos impostos pela tradição, isto é, ele deve seguir os preceitos atinentes ao código das proibições que interditam/regulam o livre fluxo do erotismo nessa sociedade.

A par da metáfora que desvela o corpo mediante sua ligação com elementos da natureza, conforme observamos em "Cantiga nossa", de José Craveirinha, e em "A curva do rio", de Paula Tavares, também verificamos que o corpo e o erotismo revelam-se através de um jogo que sobrepõe o ato da escrita à sedução, como mostra "O giz":

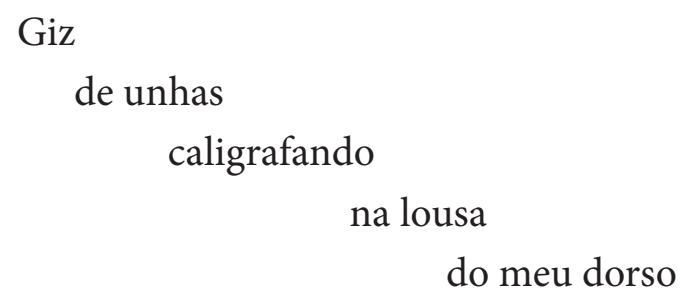

Assumo

tuas

unhadas

gizando

em minha

lousa

arrepios

no velho torso

[...]

(CRAVEIRINHA, 2010, p. 173)

Esses versos indicam a associação do erotismo ao ato da escrita, o que é sugerido desde a disposição dos versos na página, imitando as marcas (riscos, nesse caso, na horizontal) deixadas pelas unhas ao deslizar sobre a pele do eu poético. Essa relação entre corpo e escrita é apontada por Barthes (1996, p. 25), quando ele discorre sobre o prazer do texto e afirma que "o texto tem uma forma humana, é uma figura, um anagrama do corpo”. Assim, o paralelo entre erotismo, corpo e o ato da escrita é estabelecido 
considerando que os seres humanos possuem "um corpo de fruição feito unicamente de relações eróticas" e o texto, por sua vez, "não é senão a lista aberta dos fogos da linguagem" (BARTHES, 1996, p. 25).

Nos versos citados, a sobreposição de erotismo e escrita também se mostra com a aproximação do giz, instrumento destinado à grafia, às unhas que escrevem na lousa na qual se converteu o dorso da voz poética. Somado a isso, nesses versos também se vislumbra o jogo de sedução mediante a aceitação do eu poético das "unhadas gizando em minha lousa" (CRAVEIRINHA, 2010, p. 173), tendo como consequência os arrepios, indício do despertar de uma reação desencadeada pelos arranhões no corpo da voz poética.

Em paralelo a esses versos de Craveirinha e ainda com relação ao ato da escrita e a manifestação do erotismo, em versos de Paula Tavares o corpo da voz poética, que também se mostra voluntariamente, transfigura-se em uma espécie de texto grafado em braile que será decodificado pelo toque das mãos de seu par: "Deixa as mãos cegas/ Aprender a ler o meu corpo/ Que eu ofereço vales/ curvas de rio/ óleos” (TAVARES, 2007, p. 15).

Retomando o poema de Craveirinha, citado, apesar da imagem do corpo do eu poético que se entrega voluntariamente ao contato com o outro ("assumo tuas unhadas"), notamos que, embora a voz poética demonstre satisfação com a carícia sobre sua pele, ainda permanece para ela uma lacuna, como revelam os versos: “Tudo/ em termos/ de retórica/ e esta síntese/ em falso" (CRAVEIRINHA, 1996, p. 173).

A admissão de uma falência mostra que mesmo diante do encontro materializado dos amantes, como indicam os versos, sempre existirá uma lacuna, talvez irreparável, dado o fato de que, conforme as considerações de Bataille (1980), os seres humanos são seres descontínuos fadados à eterna busca pela continuidade, a qual não se atinge apenas com a plenitude física/corpórea. Assim, retomamos a metáfora que relaciona corpo e escrita, uma vez que, como assinala Barthes (1996, p. 25), o prazer do texto é irredutível a seu funcionamento textual da mesma forma que o prazer do corpo não se reduz à necessidade fisiológica, pois implica também uma "busca psicológica, independente do fim natural dado pela reprodução e pela preocupação de procriar" (BATAILLE, 1980, p. 13).

Na poética de Craveirinha, além da sobreposição do ato da escrita ao corpo, também notamos que o corpo se converte em mediador para apreensão e interação com o mundo e as pessoas ao seu redor. Nos versos de "Depois..." (CRAVEIRINHA, 2010, p. 178), o corpo feminino aproxima-se ao universo da música e dá o tom às percepções do eu poético, realizando a tarefa de, como aponta Maciel (2010), "cifrar em notação musical os solavancos do mundo":

Uma

ou outra

silhueta feminina 


\title{
é uma letra de pausa \\ na minha folha de música
}

OS

joelhos delas

centíneos solfejos

nas pautas dos meus nervos

$[\ldots]$

(CRAVEIRINHA, 2010, p. 178)

Esses versos mostram que a vida da voz poética é como uma "folha de música", uma partitura na qual os corpos femininos, a partir da interação com o mundo, ditam o ritmo da vida e desenham as notas musicais nas pautas dos nervos do eu poético. No entanto, em seguida, esta voz admite retornar a um estado de introspecção, destoando do ritmo harmônico, anteriormente em voga e ditado pelas mulheres: "Depois/ reencarno/ o cidadão sisudo/ fora do ritmo em voga" (CRAVEIRINHA, 2010, p. 178).

Enquanto nos versos de "Depois..., de Craveirinha, a mulher sugere os ritmos que marcam o compasso da vida, na poesia de Paula Tavares, como já mencionamos, o corpo feminino revela-se como um "corpo desejante" (FONSECA, 2002, p. 46), mas também se mostra ainda preso a regras e hábitos que regulam a conduta das mulheres em determinados grupos dentro da sociedade angolana, conforme mostram os versos:

\author{
neste altar sagrado \\ o que disponho \\ não é vinho nem pão \\ nem flores raras do deserto \\ neste altar o que está exposto \\ é meu corpo de rapariga tatuado \\ neste altar de paus e de pedras \\ que aqui vês \\ vale como oferenda \\ meu corpo de tacula \\ meu melhor penteado de missangas
}

(TAVARES, 1999, p. 12)

As imagens do altar, do corpo tatuado e do penteado de miçangas denotam os ritos que circundam o feminino. $\mathrm{O}$ altar remete ao contexto do sagrado, uma vez que é esse o local em que se depositam as ofertas ao(s) ente(s) superior(es); contudo, nesses versos, simbolicamente, é o corpo feminino, adornado com os elementos que prescrevem um caráter ritualístico (tatuagens e penteado de miçangas), que se apresenta como oferenda, como indica a segunda estrofe.

Ainda nesses versos, a iminente imolação simbólica do corpo feminino confere ao seu interlocutor (a quem ela se expõe como oferenda) a 
tarefa de, tal como o sacrificador que desagrega o ser imolado, desagregar o ser amado. Entretanto, vale ressaltar que, no contexto amoroso, ainda que esse ato pareça violento, é uma ação consentida (o corpo coloca-se em oferta) que colabora para a mudança da condição dos seres (BATAILLE, 1980 , p. 81). Isso porque, ainda de acordo com Bataille (1980, p. 73), os sacrifícios, em tempos remotos, eram uma oferta e a vítima assumia um sentido de divindade, o sacrifício a consagrava.

Nesse sentido, no plano amoroso, exposto nos versos com a imagem do corpo feminino constituindo uma oferta ao seu par, seu interlocutor, o aspecto sagrado para os seres humanos é sua continuidade, revelada mediante um rito solene, o encontro dos amantes, que instaura a morte dos seres descontínuos (BATAILLE, 1980, p. 74) por meio da união e da cumplicidade.

Apesar da comunhão entre o eu poético e seu par, observada nos versos do poeta moçambicano e da poeta angolana, até o momento analisados, verificamos que em alguns poemas desses autores a "ausência do objeto desse amor" (PADILHA, 2002, p. 18) causa profunda angústia, desalento e um agudo esvaziamento da voz poética diante de uma repentina despedida que tende a transformar essa ausência "em prova de abandono" (BARTHES, 1990, p. 27).

Essa "prova de abandono" à qual o eu poético é submetido pode decorrer tanto da quebra do laço entre os amantes com uma despedida não se sabe se breve, mas que pelo menos deixa o anseio pelo regresso -, quanto pela ação irreversível da morte que intercepta o caminho do par amoroso.

O temor da morte, segundo Becker (2007, p. 31), está entre os principais elementos que movem a humanidade. Segundo ele (2007, p. 32), as religiões históricas (o autor cita o cristianismo, o hinduísmo e o budismo) dedicaram-se ao problema de como suportar o fim da vida. Sobre essa mesma questão debruça-se a filosofia quando esta, ainda segundo Becker (2007, p. 32), assumiu o lugar da religião e a morte tornou-se a "musa da filosofia" desde os gregos até o existencialismo moderno.

Contudo, embora tendo o aparato da religião e da filosofia, meios que auxiliam os seres humanos na tentativa de compreensão e melhor convivência com a premissa de que a morte é inerente à condição humana, por mais que se saibam como seres finitos, as pessoas demonstram aflição, desamparo e impotência diante do momento que decreta o fim da vida, ou ao menos o fim do corpo físico, da matéria.

Na poesia de Craveirinha, esse abalo diante da morte pode ser vislumbrado no instante do penoso adeus, contrastando com a delicadeza, perfume e vivacidade das rosas multicores: "Um braçado/ polícromo de flores/ perfumado/ De profundis / de coroas.//Tão duro/ assim lacônico/ nosso adeus de rosas, Maria"” (CRAVEIRINHA, 2010, p. 127). 
Além da dificuldade do momento do adeus, o eu poético na obra de Craveirinha também demonstra indignação diante da ação da morte que, nos versos de "A Grande Maldita", surge personificada: "Isso a Grande Maldita/ nunca deveria ter feito.// Chegar de surpresa/e levar-te./ ...// Sem merecer/ ainda estar/ ao teu lado" (CRAVEIRINHA, 2010, p. 129). Nesses versos, a morte personificada é apresentada como uma adversária que, sorrateiramente, invadiu a cena e levou consigo a companheira do eu poético. Esse momento da partida, da morte propriamente dita, é mostrado nesse poema com as reticências que ocupam o espaço de um verso (ver trecho citado).

Além disso, notamos que a indignação da voz poética expõe-se pela forma como ela se refere à morte, "Grande Maldita", e pelo fato de, na perspectiva do eu poético, a morte ter chegado em uma hora imprópria, sendo ela ainda não merecedora de estar ao lado da companheira do eu poético. Assim, nos versos citados, a morte é uma inimiga, ela sufoca a vida, propaga o caos e a indignação daqueles que, inconformados, tal como o eu poético, veem os entes queridos partirem. Porém, em oposição a essa visão apocalíptica da morte, vale mencionar que também existe entre os seres humanos uma visão da morte, segundo assinala Becker (2007, p. 11), como "a última elevação ritual para uma forma de vida superior, para o desfrute da eternidade de alguma forma”.

Diante da morte e de um "infinito amor a doer" (CRAVEIRINHA, 2010, p. 79), o eu poético, nos versos de Craveirinha, não encontra outra opção senão a de fazer vazar sua dor, como indicam os versos: "Lágrimas?/ Ou apenas/ dois intoleráveis/ ardentes gumes de névoa/ acutilando-me cara abaixo?" (CRAVEIRINHA, 2010, p. 120), e também “Do avesso das pálpebras/ gotejam missangas/ de sal” (CRAVEIRINHA, 2010, p. 121). Vertidas e deslizando sobre a face do eu poético, lá se vão as "missangas/ de sal" até a hora em que "quando na desolada ressonância da saudade/ o eco silencia soluços de amargura” (CRAVEIRINHA, 2010, p. 135).

Ainda sobre a morte, em outros versos observamos que a vida conjugal de Maria e seu par tornou-se uma "cerimônia agora interrompida” (CHAVES, 1999, p. 161) e no ambiente doméstico até os objetos parecem "desabitados da presença de Maria" (MENDONÇA apud CHAVES, 1999, p. 163), deixando o eu poético consternado: "Nos primeiros tempos/ como era inábil/ nas minhas mãos/ a viuvez da vassoura" (CRAVEIRINHA, 2010, p. 139). Em paralelo, nesse mesmo espaço doméstico também notamos que a solidão e o atordoamento do eu poético, devido à ausência de Maria, abrem espaço para a manifestação do fenômeno do duplo, nos termos de Freud (1969), como revela o poema "Café":

\section{Muito de manhã \\ ajunto à xícara \\ o respectivo pires \\ uma colherinha \\ e o café}

A mim mesmo peço

que vá buscar o açucareiro 
Uma.

Duas.

Três colheres de açúcar.

Mexo. Provo. Está doce.

E na incongruente imensidão da casa

lacónico vou sorvendo

Tudo amargo.

(CRAVEIRINHA, 2010, p. 141)

Os versos iniciais evocam uma cena do cotidiano a partir da preparação da refeição matutina do eu poético que, em virtude da ausência de outra pessoa na casa, pede a si mesmo, como se dialogasse com outra pessoa, que providencie o açucareiro para finalizar o preparo do café. Nesse momento observamos o fenômeno do duplo, uma vez que ocorre, nos termos de Freud (1969, p. 252), a substituição do self por um estranho, a duplicação, divisão e intercâmbio do self, dado o fato de, nesses versos, a voz poética dirigir-se a si mesma como se estivesse conversando com um "outro", seu duplo. Em outro poema intitulado "Os dois eus e a solidão", além do "duplo" observa-se que a solidão para a voz poética atinge uma dimensão incomensurável a ponto de quase transformar-se em um ser: "Em $\mathrm{mim} /$ a solidão é já uma pessoa// Onde a um eu que não chora/ um meu outro eu/ chora tudo/ pelos três" (CRAVEIRINHA, 2010, p. 146).

Retomando o olhar para o poema "Café", ainda verificamos uma oposição entre o que se passa no exterior, o ambiente da casa, e as percepções interiores do eu poético. A doçura do café contrasta com o instante em que o eu poético, lacônico, bebe o café, momento representado, no poema, pela sequência gráfica de pontos que preenchem o espaço de um verso, e não sente seu sabor adocicado, pelo contrário, ele constata que tudo está amargo, pois seu estado de desolação pela ausência de Maria o faz perceber a casa como imensa e o impede de apreciar o café.

Na poética de Craveirinha, na impossibilidade angustiante de suportar a ausência da amada, ausência experimentada como abandono irreparável e que, como observa Maciel (2010, p.195), "converte o cotidiano em discreto purgatório” e em um acúmulo de vazios, o eu poético, aludindo a Camões, vislumbra a morte como a "senha para o tão ansiado encontro com sua Dinamene" (MACIEL, 2010, p. 195), conforme revela o poema "O mote de Camões":

Exausto

de insónias

peço ajuda ao bom Luís Vaz de Camões.

$[\ldots]$ 
Ele

o grão-sonhador que lambeu

suas crostas

imperfilando

em verso

deu-me

o mote:

Efémeros são os oiros dos biltres.

Vãos os poderes da espada e da pólvora.

Louvada seja a Dinamene

e Maria louvada seja também

E ambos entoamos.

(CRAVEIRINHA, 2010, p. 149)

Esses versos aludem à dor da perda de Dinamene, expressa em versos de Camões ${ }^{6}$, e ao sofrimento do eu poético que, nos versos citados, no ápice da exaustão e insônia, recorre ao grande poeta português, o qual deu à voz poética o mote indicativo de que superior às riquezas materiais e às conquistas bélicas é a exaltação da amada, ainda que já morta. Além disso, essa adoração da amada e a possibilidade de encontrá-la em outra esfera, conforme pressupõe a referência à Dinamene, pode configurar uma tentativa, nos termos de Becker (2007, p. 11), de "evitar a fatalidade da morte e vencê-la mediante a negação de que ela seja o destino final do homem".

Em paralelo aos versos citados, na poética de Paula Tavares também observamos uma voz poética, com modulação de uma voz feminina, que sofre diante da partida do amado, revelada pelo vento como sendo uma partida sem regresso devido à ação irreversível da morte: “Todos os dias conservei aceso o fogo sagrado/ Na hora dos fantasmas/ o vento diz-me a tua voz/ é a voz das viagens/ sem regresso" (TAVARES, 2001, p. 13).

A sensação de abandono para o eu poético da obra dos autores em tela ocorre devido ao desconforto diante da morte, mas esse desamparo também pode se dar mediante o distanciamento, talvez momentâneo, da figura amada, situação que, se comparada ao embate com a morte, é mais palatável, pois é possível alimentar a expectativa do retorno. Nesse sentido, vejamos os versos:

O meu amado chega e enquanto despe as sandálias de couro

Marca com o seu perfume as fronteiras do meu quarto.

Solta a mão e cria barcos sem rumo no meu corpo.

Planta árvores de seiva e folhas.

Dorme sobre o cansaço

embalado pelo momento breve da esperança.

Traz-me laranjas. Divide comigo os intervalos da vida.

Depois parte. 
Deixa perdidas como um sonho as belas sandálias de couro. (TAVARES, 1999, p. 19)

Nesses versos notamos que o encontro dos amantes é permeado pelo despertar dos sentidos: o olfato, o perfume do couro das sandálias do amado e o tato que se mostra com a imagem das mãos que, como barcos em alto mar, navegam pelo corpo feminino. Ainda com relação ao perfume emanado do couro das sandálias, vale ressaltar que a referência ao signo do boi é recorrente na poesia de Paula Tavares e constitui uma alusão às cores, às fragrâncias e a elementos peculiares da região do sul de Angola (a poeta nasceu na província da Huíla), área na qual, como aponta Carmen Tindó $\mathrm{Secco}^{7}$, "a pastorícia e a agricultura definem o modo de vida, os ritos, os contratos, enfim, os costumes e a história desses".

Os versos mostram que o encontro da voz poética com seu amado é embalado pelo contentamento, como indica a imagem, no quarto verso, do plantio de árvores de seiva e flores, denotando o frutificar da alegria que, em seguida, é substituída pela sensação da fugacidade dessa relação, pois eles compartilham "os intervalos da vida" e logo o amado parte. O distanciamento do amado é expresso, no poema, pela sucessão de pontos gráficos que, ocupando o espaço de um verso, simboliza a suspensão do encontro. Por outro lado, em outros versos da poeta o abandono é percebido com a presença das sandálias, vestígio daquele que se foi: “Todas as feridas de sangue/não esgotaram o meu rio/tropeço nas sandálias de couro de boi/ morro porque estou ferida de amor" (TAVARES, 1999, p.13).

Ainda que se configurem como índice da ausência, as sandálias também dão à voz poética o lastro para almejar e nutrir a esperança do regresso alentador da figura masculina, como exprime o verso: "Deixa perdidas como um sonho as belas sandálias de couro" (TAVARES, 1999, p. 19).

Em outros versos de Paula Tavares também observamos que a relação dos amantes é fruto de um acolhimento incondicional da figura feminina que, em virtude do afeto, não impõe obstáculos ou indaga o amado sobre o que ela não conhece a respeito dele:

Não conheço nada do país do meu amado

Não sei se chove, nem sinto o cheiro das laranjas.

Abri-lhe as portas do meu país sem perguntar nada

Não sei que tempo era

O meu coração é grande e tinha pressa

$[\ldots]$

(TAVARES, 1999, p. 20)

Embora exista um movimento de receptividade, conforme indicam os versos citados, a voz poética não apresenta seu país ao amado, não 
lhe fala das colheitas ou da seca, mas deixa que ele conheça o país dela a partir da observação e do desenrolar das experiências cotidianas, como mostram os versos: "Não lhe falei do país, das colheitas, nem da seca/ Deixei que ele bebesse do meu país o vinho o mel a carícia/ Povoei-lhe os sonhos de asas, plantas e desejo" (TAVARES, 1999, p. 20).

Nos versos subsequentes, notamos que o eu poético tece uma sutil comparação entre seu país e o país do amado. A voz poética assinala que o país do amado deve ser um país estranho, pois ele não conhece ou não identifica no país dela alguns indícios do ciclo da vida, tais como a hora da colheita, o canto dos pássaros, nem em sentido metafórico conhece o sabor da terra de manhã, como revelam os versos: "Deve ser um estranho país/ o país do meu amado/pois não conheço ninguém que não saiba/a hora da colheita/o canto dos pássaros/o sabor da sua terra de manhã cedo" (TAVARES, 1999, p. 20). Esse descompasso no conhecimento de determinados códigos que regem a vida indica que no país do amado esses referenciais culturais podem não ter a mesma importância que possuem no país da voz poética, pois eles detêm repertórios culturais distintos.

O silêncio da figura masculina prolonga-se. Ele não fornece nenhuma informação ou explicação sobre si mesmo ou sobre seu país para a voz poética - "Nada me disse o meu amado" (TAVARES, 1999, p. 21) - e na sequência vislumbramos a transitoriedade do encontro, a partida do amado: "Chegou/ Mora no meu país não sei por quanto tempo/ É estranho que se sinta bem/ e parta” (TAVARES, 1999, p. 21).

Além de indicar a transitoriedade da presença do amado, esses versos também apontam para o efeito de estranhamento, o qual, segundo Bhabha (1998, p. 31), é inerente ao rito de iniciação extraterritorial e intercultural. Nesse sentido, com relação aos versos citados, o efeito de "estranhamento" ocorre, pois mesmo sentindo-se bem, mesmo tendo sido acolhido e tendo levado consigo influências do país da voz poética - "Volta com um cheiro de país diferente/ Volta com os passos de quem não conhece a pressa" (TAVARES, 1999, p. 21) -, o amado retorna ao seu país, restando à voz poética "o silêncio aberto/de um grito/sem som nem gesto/ apenas o silêncio aberto assim ao grito/solto ao intervalo das lágrimas" (TAVARES, 1999, p. 16).

\section{CONSIDERAÇÕES FINAIS}

A leitura comparada das poéticas de José Craveirinha e de Paula Tavares no que se refere à expressão do erotismo, em seus versos, mostrou-nos que este ocorre não apenas com a exposição dos corpos, mas também mediante uma busca do ser pela continuidade em uma dimensão psicológica e afetiva. Também percebemos que o erotismo se expõe na poesia dos autores a partir de imagens metafóricas que associam mulher e natureza e também corpo e escrita. E ainda a esse respeito, notamos que na poesia de Paula Tavares é recorrente uma voz com modulação feminina que expressa 
seus desejos, da ordem do corpo, e também exprime aspirações afetivas, contrariando a tendência mais frequente no meio literário, ou seja, a manifestação de uma voz com modulação masculina que se dirige ao feminino na exposição dos anseios amorosos.

Além disso, na apresentação do encontro dos amantes, nos versos dos poetas analisados, observamos que o enlace amoroso, na poética de Craveirinha, é interceptado pelo abandono que se revela na forma da morte da amada, ao passo que na poesia de Paula Tavares o rompimento do laço entre os amantes ocorre mais em virtude da partida, talvez sem regresso, da figura masculina.

Assim, embora os enlaces afetivos sejam uma forma de buscar a transição do ser da descontinuidade para a continuidade, tornando-se, desse modo, um ser humano mais pleno, é necessário atentar para o fato de que no meio do conforto e da felicidade, "cresce insondável o vazio" (TAVARES, 1985, p. 15) que assombra e, muitas vezes, inesperadamente, esfacela os vínculos mais caros ao ser humano.

\section{REFERÊNCIAS BIBLIOGRÁFICAS}

BARTHES, Roland. Fragmentos de um discurso amoroso. Trad. Hortência dos Santos. Rio de Janeiro: Francisco Alves Editora, 1990.

. O prazer do texto. Trad. J. Guinsburg. São Paulo: Editora Perspectiva, 1996.

BATAILLE, Georges. O erotismo. Trad. João Benard da Costa. Lisboa: Moraes Editores, 1980.

BEAUVOIR, Simone de. O segundo sexo: fatos e mitos. Trad. Sérgio Milliet. São Paulo: Difusão europeia do livro, 1970.

BECKER, Ernest. A negação da morte. Trad. Luiz Carlos do Nascimento Silva. Rio de Janeiro: Record, 2007.

BHABHA, Homi K. O local da cultura. Trad. Gláucia Renate Gonçalves, Eliana Lourenço de Lima Reis, Myriam Ávila. Belo Horizonte: Ed. UFMG, 1998.

BÍBLIA SAGRADA. Trad. Centro Bíblico Católico. 106. ed. São Paulo: Editora Ave Maria, 1996.

CAMÕES, Luís de. Versos e alguma prosa de Luís de Camões. Eugénio de Andrade (Org.). Lisboa: Moraes Editores, 1977.

CHAVES, Rita. José Craveirinha, da Mafalala, de Moçambique, do mundo. In: Via Atlântica, n. 3, dez. 1999, p. 140-168. Disponível em: $<$ http://www.fflch.usp.br/dlcv/posgraduacao/ecl/publicado.html> Acesso em: 06 maio 2012. 
CRAVEIRINHA, José. Antologia poética. Ana Mafalda Leite (Org.). Belo Horizonte: Editora UFMG, 2010.

FONSECA, Nazareth Soares. Corpo e voz em poemas brasileiros e africanos escritos por mulher. In: DUARTE, Constância Lima \& SCARPELLI, Marli Fantini. Gênero e representação nas literaturas de Portugal e África. Coleção Mulher \& Literatura, Vol. III. Belo Horizonte : UFMG/ FALE, 2002.

FREUD, Sigmund. O estranho. Trad. Jayme Salomão. In: Obras completas de Sigmund Freud: edição standard brasileira, v. XVII. Rio de Janeiro: Imago, 1969.

MACIEL, Emílio. Angulações do chamamento: biobibliografia de José Craveirinha. In: CRAVEIRINHA, José. Antologia poética. Ana Mafalda Leite (Org.). Belo Horizonte: Editora UFMG, 2010.

PADILHA, Laura Cavalcante. Como uma segunda pele ou poesia feminina africana, em expansão. In: DUARTE, Constância Lima \& SCARPELLI, Marli Fantini. Gênero e representação nas literaturas de Portugal e África. Coleção Mulher \& Literatura, v. III. Belo Horizonte: UFMG/ FALE, 2002.

. Paula Tavares e a semeadura das palavras. In: CAMPOS, Maria do Carmo Sepúlveda, SALGADO, Maria Teresa. (Org.). África e Brasil: Letras em laços. São Paulo: Atlântica Editora, 2006.

PRATT, Mary Louise. Mulher, literatura e irmandade nacional. Trad. Valéria Lamego. In: HOLLANDA, Heloisa Buarque de (Org.). Tendências e impasses: o feminismo como crítica da cultura. Rio de Janeiro: Rocco, 1994.

QUINTERO-RIVERA, Mareia. A cor e o som da nação: a ideia de mestiçagem na crítica musical do Caribe hispânico e do Brasil. São Paulo: Annablume/FAPESP, 2000.

SECCO, Carmen Lúcia Tindó Ribeiro. Ruminações do tempo e da memória na poesia de Paula Tavares. Disponível em: <http://www.ueangola. com> Acesso em: 05 maio 2012.

TAVARES, Paula. Dizes-me coisas amargas como os frutos. Lisboa: Caminho, 2001.

. O lago da lua. Lisboa: Caminho, 1999.

. Manual para amantes desesperados. Lisboa: Caminho, 2007.

. Ritos de passagem. Luanda: União dos escritores angolanos, 1985.

Recebido para publicação em 30/05/12.

Aprovado em 30/06/2012. 


\section{NOTAS}

1 Conforme Bataille (1980, p. 27), o que difere o erotismo do homem da sexualidade animal é a vida interior, pois no animal não existe nada que seja semelhante a um pôr em questão.

2 No meio literário, a aproximação entre mulher e natureza ocorreu em diferentes épocas como, por exemplo, na Era Medieval (século XII) com a poesia trovadoresca, no Arcadismo (século XVIII), no Romantismo (século XIX) e no Modernismo (século XX) e em uma concepção de gênero, como assinala Beauvoir (1970), ao indicar que a mulher, na literatura, foi metamorfoseada em flores, frutos e pássaros por poetas do Ocidente e do Oriente.

$3 \mathrm{Na}$ literatura e nos relatos históricos é recorrente a associação do corpo feminino ao nacional e à conquista de um território, indicando a dominação. A esse respeito ver PRATT, Mary Louise. Mulher, literatura e irmandade nacional. Trad. Valéria Lamego. In: HOLLANDA, Heloisa Buarque de (Org.). Tendências e impasses: o feminismo como crítica da cultura. Rio de Janeiro: Rocco, 1994. E também: QUINTERO-RIVERA, Mareia. A cor e o som da nação: a ideia de mestiçagem na crítica musical do Caribe hispânico e do Brasil. São Paulo: Annablume/FAPESP, 2000.

4 A expressão "De profundis", nesse poema, é uma possível alusão ao Salmo 129 - "De profundis - Penitência e esperança”, o qual expõe o clamor à misericórdia de Deus para que Ele conceda o perdão e a redenção aos que se dirigem a Ele. Assim, a referência ao salmo, nesses versos, é propícia porque exprime as súplicas mais comuns diante da proximidade da morte. Ver BÍBLIA SAGRADA. Trad. Centro Bíblico Católico. 106. ed. São Paulo: Editora Ave Maria, 1996.

5 Entre os muitos nomes evocados pelo poeta, em seus versos, destaca-se o nome de Maria, companheira de Craveirinha, que faleceu em 1979 e a quem o autor dedicou a obra intitulada "Maria". Vale ressaltar que atentamos para esse fato, mas não realizamos uma leitura de perspectiva autobiográfica dos poemas nos quais aparece a imagem de Maria.

6 Ver, por exemplo, os sonetos de Camões "Ah minha Dinamene!Assim me deixaste" e "Alma minha gentil, que te partiste". Ver: CAMÕES, Luís de. Versos e alguma prosa de Luís de Camões. Eugénio de Andrade (Org.). Lisboa: Moraes Editores, 1977.

7SECCO, Carmen Lúcia Tindó Ribeiro. Ruminações do tempo e da memória na poesia de Paula Tavares. Disponível em: <http://www.ueangola.com> Acesso em: 06 maio 2012. 